\title{
Microsatellite instability is a biomarker for immune checkpoint inhibitors in endometrial cancer
}

\author{
Hitomi Yamashita ${ }^{1}$, Kentaro Nakayama ${ }^{1}$, Masako Ishikawa $^{1}$, Kohei Nakamura ${ }^{1}$, \\ Tomoka Ishibashi ${ }^{1}$, Kaori Sanuki ${ }^{1}$, Ruriko Ono ${ }^{1}$, Hiroki Sasamori ${ }^{1}$, Toshiko \\ Minamoto ${ }^{1}$, Kouji Iida ${ }^{1}$, Razia Sultana ${ }^{1}$, Noriyoshi Ishikawa ${ }^{2}$ and Satoru Kyo ${ }^{1}$ \\ ${ }^{1}$ Department of Obstetrics and Gynecology, Shimane University School of Medicine, Izumo, Japan \\ 2 Department of Organ Pathology, Shimane University School of Medicine, Izumo, Japan \\ Correspondence to: Kentaro Nakayama, email: kn88@med.shimane-u.ac.jp \\ Keywords: microsatellite instability; endometrial cancer; immune checkpoint inhibitor; immunohistochemistry; mismatch repair \\ protein; Immunology \\ Received: September 07, $2017 \quad$ Accepted: October 28, $2017 \quad$ Published: December 31, 2017 \\ Copyright: Yamashita et al. This is an open-access article distributed under the terms of the Creative Commons Attribution License 3.0 (CC \\ BY 3.0), which permits unrestricted use, distribution, and reproduction in any medium, provided the original author and source are credited.
}

\section{ABSTRACT}

In recent years, it has become evident that tumor cells have immune escape mechanisms, and immune checkpoint inhibitor therapy (anti-PD-1/PD-L1 antibody) has shown benefit in various cancers. In endometrial tumors with microsatelliteinstability (MSI), somatic mutations have the potential to encode "non-self" immunogenic antigens, and lymphocytes have been shown to infiltrate the tumor. Therefore, immune checkpoint inhibitor therapy might be effective in endometrial cancers with MSI. Expression of mismatch repair (MMR) proteins (MLH1, PMS2, MSH2, and MSH6), the presence of tumor-infiltrating lymphocytes (CD8+), and PD-1/PD-L1 expression were assessed by immunohistochemistry in 149 patients with endometrial cancer. We examined whether tumors with MSI had an enhanced immune microenvironment and whether MSI could be a predictor of the therapeutic effect of PD-1/PD-L1 immunotherapy in endometrial cancer. Loss of MMR protein expression was identified in $42(28.2 \%)$ of 149 patients (MSI group) with endometrial cancer. There was no significant relationship between MSI status and age $(p=0.193)$, histological grade $(p=0.097)$, FIGO stage $(p=0.508)$, pelvic lymph node metastasis $(p=0.139)$, or depth of myometrial invasion $(p=0.494)$. However, the presence of tumor-infiltrating lymphocytes (CD8+) and PD-L1/PD-1 expression were significantly higher in the MSI group compared to the microsatellite-stable group $(p=0.002, p=$ 0.001 , and $p=0.008$, respectively). These results suggest that immune checkpoint inhibitors (anti-PD-1/PD-L1 antibody) could be effective in endometrial cancers with MSI. The presence of MSI may be a biomarker for good response to PD-1/PD-L1 immunotherapy in endometrial cancer.

\section{INTRODUCTION}

Because of the increase in genetic mutation that frequently accompanies tumorigenesis, tumor cells express neoantigens that are different from those on normal cells. Tumor antigens are processed by dendritic cells, and become expressed on the cell surface, together with major histocompatibility complex I and II (MHC class 1 and 2). When CD8 T cells recognize tumor antigens bound to $\mathrm{MHC}$ class 1 , they become cytotoxic $\mathrm{T}$ lymphocytes
(CTLs), which can attack cancer cells. However, recent studies have shown that tumor cells have immune escape mechanisms $[1,2]$. The programmed cell death-1 (PD1) and PD-1 ligand 1 (PD-L1) pathway is one such immune escape mechanism. When PD-1 expressed on CTLs binds to PD-L1 expressed on cancer cells, the antitumor immune response mediated by CTLs is suppressed. Pharmacologic inhibition of the PD-1/PD-L1 pathway allows for reactivation of the immune response against the tumor [3]. Blockade of this pathway with antibodies to 
PD-1 and PD-L1 has been reported to be effective in many different types of cancers [4-6]. In addition, it is suggested that immune checkpoint inhibitors may be effective when there is a high infiltration of CD8 lymphocytes into the tumor [16].

Anti-PD-1/PD-L1 antibodies have been used in clinical practice; however, they are not effective in all patients, and response efficiencies when patients of various cancer types are treated by PD-1 antibody are reported to be 20\%-30\% [6-8]. Moreover, side effects peculiar to immune checkpoint inhibitors (pulmonary toxicity, type 1 diabetes, and colitis) have been reported in patients receiving anti-PD-1/PD-L1 antibodies. Grade 3 or 4 drug-related adverse events occurred in $14 \%$ of patients, and, in one study, there were three deaths from pulmonary toxicity [6]. Because of the high drug price and serious reported side effects, discovering biomarkers for immune checkpoint inhibitors is urgent.

It has been reported that, in patients with high PDL1 expression on tumor cells, PD-1/PD-L1 blockade has a greater therapeutic effect compared to that in patients with low expression of PD-L1 [9-13]. However, it has also been reported that anti-PD-1 antibody is effective even in patients without PD-L1 expression [11]. There are reports that the expression of PD-L1 is dynamic and therefore not suitable as a biomarker. PD-L1 expression on tumor cells in non-small cell lung cancer reveals intratumoral heterogeneity, and can differ between surgical and biopsy specimens. There are no clear criteria for the evaluation of PD-L1 expression, and there are also differences in PD-L1 expression between commonly used assays [14, 15].

In recent years, it has been reported that tumors with higher numbers of somatic mutations (mutation burden rich) are more immunogenic, and immune checkpoint inhibitors are effective for tumors that are mutation burden rich [17-19]. For example, in smokers, the number of genetic mutations in tumors is increased, and immune checkpoint inhibitors have been effective in these patients $[19,20]$. Le and colleagues reported significant responses of tumors with microsatellite instability (MSI) to antiPD-1 antibody in patients who failed conventional therapy [18]. Cancers with MSI have many genetic mutations. High immunogenicity and more immune cell infiltration into the tumor have also been observed in tumors with MSI. Therefore, immune checkpoint inhibitors are thought be effective for tumors with MSI [21].

Endometrial cancer is a gynecological tumor that is frequently MSI positive. Based on genetic features, The Cancer Genome Atlas Research Network provided a new classification system for endometrial carcinoma, which defines four subgroups of cancer (polymerase epsilon (POLE)-ultramutated, MSI-hypermutated, copy number low, and copy number high) [22].

Endometrial cancer is the fifth leading cause of cancer death in the world, and is the most common gynecological cancer [23]. However, advanced endometrial cancer and recurrent endometrial cancer have poor prognosis with current treatments [24-28]. Therefore, we have hypothesized that prognosis may be improved using immune checkpoint inhibitors in endometrial tumors with MSI. In the present study, we investigated biomarkers for predicting the effect of immune checkpoint inhibitors using immunostaining in endometrial carcinoma with MSI.

\section{RESULTS}

\section{Patients' clinicopathological characteristics}

In the present study, 96 of 149 cases were diagnosed as FIGO stage I, 16 were diagnosed as FIGO stage II, 32 were diagnosed as FIGO stage III, and 5 were diagnosed as FIGO stage IV. The patients were treated initially as follows: total hysterectomy in 59 patients, modified radical hysterectomy in 73 , and radical hysterectomy in 13. Four patients underwent chemotherapy and/ or radiotherapy without surgery due to complications. Retroperitoneal lymph node dissection was performed in 124 patients. Radiotherapy (whole pelvic irradiation) and/ or chemotherapy (paclitaxel $175 \mathrm{mg} / \mathrm{m}^{2}$ and carboplatin area under the curve $=5 \mathrm{mg} / \mathrm{m}^{2}$ ) was performed postoperatively in patients with high recurrence risk (deep myometrial invasion, grade 2 or 3; lymph node metastasis; or lymphovascular space invasion). A summary of the clinicopathological characteristics of the patients is provided in Table 1.

In the present study, 42/149 patients were MSIpositive (28.2\%) (MSH2 loss, 21 cases; MSH6 loss, 14 cases; MLH1 loss, 20 cases; and PMS2 loss, 3 cases). Figure 1 shows representative cases that were positive and negative for MLH1, MSH2, MSH6, and PMS2. There was no significant relationship between MSI status and age ( $p$ $=0.193)$, histological grade $(p=0.097)$, FIGO stage $(p=$ $0.508)$, pelvic lymph metastasis $(p=0.139)$, or depth of myometrial invasion $(p=0.494)$ (Table 1$)$.

\section{Relationships between MSI and CD8, PD-L1, and PD-1 expression}

The relationships between MSI and the expression of CD8, PD-L1, and PD-1 were assessed using a Chisquared test. The positive rate of CD8 expression in MSI cases was higher than that in MSS cases $(p=0.002)$ (Table 2 , Figure 2A-2B). Similarly, the expression rates of PD-L1 and PD-1 were higher in MSI cases than in MSS cases ( $p$ $=0.008, p=0.001$, respectively) (Tables 3 and 4, Figure 2C-2F). 

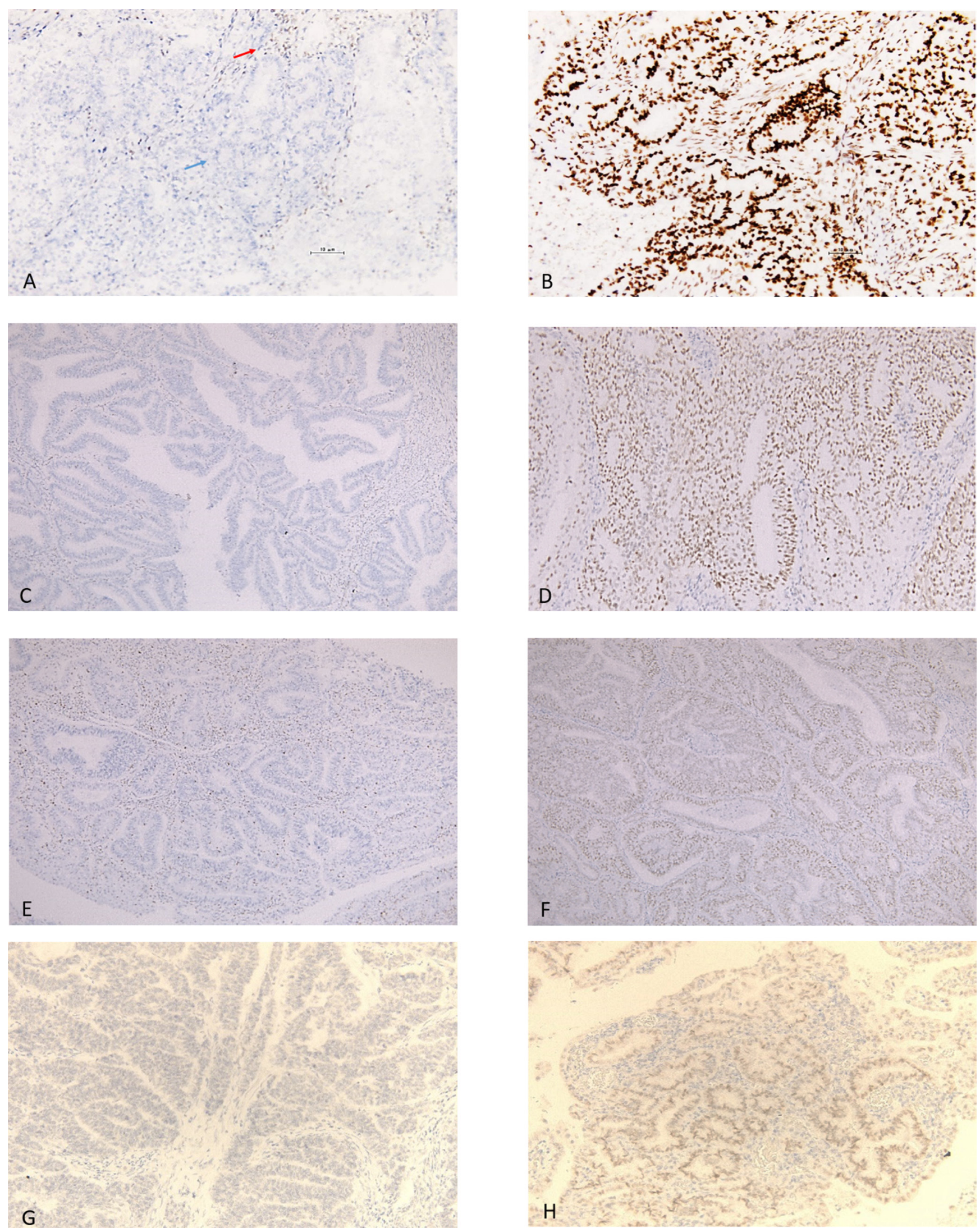

Figure 1: Immunostaining of mismatch repair proteins. A. Loss of expression of MLH1. The immunostaining is positive in stromal cells (red arrow) and negative in tumor cells (blue arrow). B. Expression of MLH1. C. Loss of expression of MSH2. D. Expression of MSH2. E. Loss of expression of MSH6. F. Expression of MSH6. G. Loss of expression of PMS2. H. Expression of PMS2. 
Table 1: Characteristics of endometrial cancer patients

\begin{tabular}{|c|c|c|c|}
\hline \multicolumn{1}{|c|}{ Characteristic } & MSI (+) & MSI (-) & p-Value \\
\hline Age-no. (\%) & N=42 & N=107 & \\
\hline$<60$ & & & 0.193 \\
\hline$\geq 60$ & $25(60)$ & $51(48)$ & \\
\hline Grade-no. (\%) & $17(40)$ & $56(52)$ & \\
\hline G1 & & & 0.097 \\
\hline G2, 3 & $18(43)$ & $62(58)$ & \\
\hline FIGO Stage-no. (\%) & $24(57)$ & $45(42)$ & \\
\hline I, II & & & 0.508 \\
\hline III, IV & $30(71)$ & $82(77)$ & \\
\hline Pelvic lymph metastasis-no. (\%) & $12(29)$ & $25(23)$ & \\
\hline No & & & 0.139 \\
\hline Yes & $28(80)$ & $80(90)$ & \\
\hline Muscle invasion-no. (\%) & $7(20)$ & $9(10)$ & \\
\hline$<50 \%$ & & & 0.494 \\
\hline$\geq 50 \%$ & $25(61)$ & $69(67)$ & \\
\hline
\end{tabular}

Table 2: Relationship between status of MSI and CD8 expression

\begin{tabular}{|c|c|c|c|}
\hline Parameter & MSI (+) & MSI (-) & p-Value \\
\hline & $\boldsymbol{N}=\mathbf{4 2}$ & $\boldsymbol{N}=\mathbf{1 0 7}$ & \\
\hline CD8-no. (\%) & & & 0.002 \\
\hline positive & $23(55)$ & $30(28)$ & \\
\hline negative & $19(45)$ & $77(72)$ & \\
\hline
\end{tabular}

Table 3: Relationship between status of MSI and PD-L1 expression

\begin{tabular}{|c|c|c|c|}
\hline Parameter & MSI (+) & MSI (-) & p-Value \\
\hline & $\boldsymbol{N}=\mathbf{4 2}$ & $\boldsymbol{N}=\mathbf{1 0 7}$ & \\
\hline PD-L1-no. (\%) & & & 0.008 \\
\hline positive & $20(48)$ & $27(25)$ & \\
\hline negative & $22(52)$ & $80(75)$ & \\
\hline
\end{tabular}

Table 4: Relationship between status of MSI and PD-1 expression

\begin{tabular}{|c|c|c|c|}
\hline Parameter & MSI (+) & MS I (-) & p-Value \\
\hline & $\boldsymbol{N}=\mathbf{4 2}$ & $\boldsymbol{N}=\mathbf{1 0 7}$ & \\
\hline PD-1-no. (\%) & & & 0.001 \\
\hline positive & $12(29)$ & $8(7)$ & \\
\hline negative & $30(71)$ & $99(93)$ & \\
\hline
\end{tabular}

\section{MSI analysis}

We conducted genomic microsatellite instability analysis in 12 cases evaluated as MSI by IHC. All cases were diagnosed as MSI by microsatellite analysis; therefore, we believe that MSI assessment by immunostaining was valid (Figure 3).

\section{Univariate analysis of prognostic factors in patients with endometrial carcinoma}

In the univariate analysis, there was no significant difference in PFS or OS between the MSI group and the MSS group (Figure 4A-4B). Similarly, there was no significant difference in OS between the PD-L1 $(+)$ and PD-L1(-) cases, although PFS was significantly prolonged in the PD-L1(+) cases compared to the PD-L1(-) cases (Figure 4C-4D). There was no significant difference in PFS or OS between the PD-1(+) and PD-1(-) cases (Figure 
4E-4F). There was no significant difference in OS between the CD8(+) and CD8(-) cases, but PFS was significantly prolonged in CD8(+) cases as compared to CD8(-) cases (Figure 4G-4H). We suspect that second or third line chemotherapies may contribute to overall survival after the first recurrence. This may explain why there was no significant difference in OS between CD8(+) and CD8(-) cases or between PD-L1(+) and PD-L1(-) cases.

\section{DISCUSSION}

Seventy-five percent of women diagnosed with endometrial cancer have early stage disease (stage I or
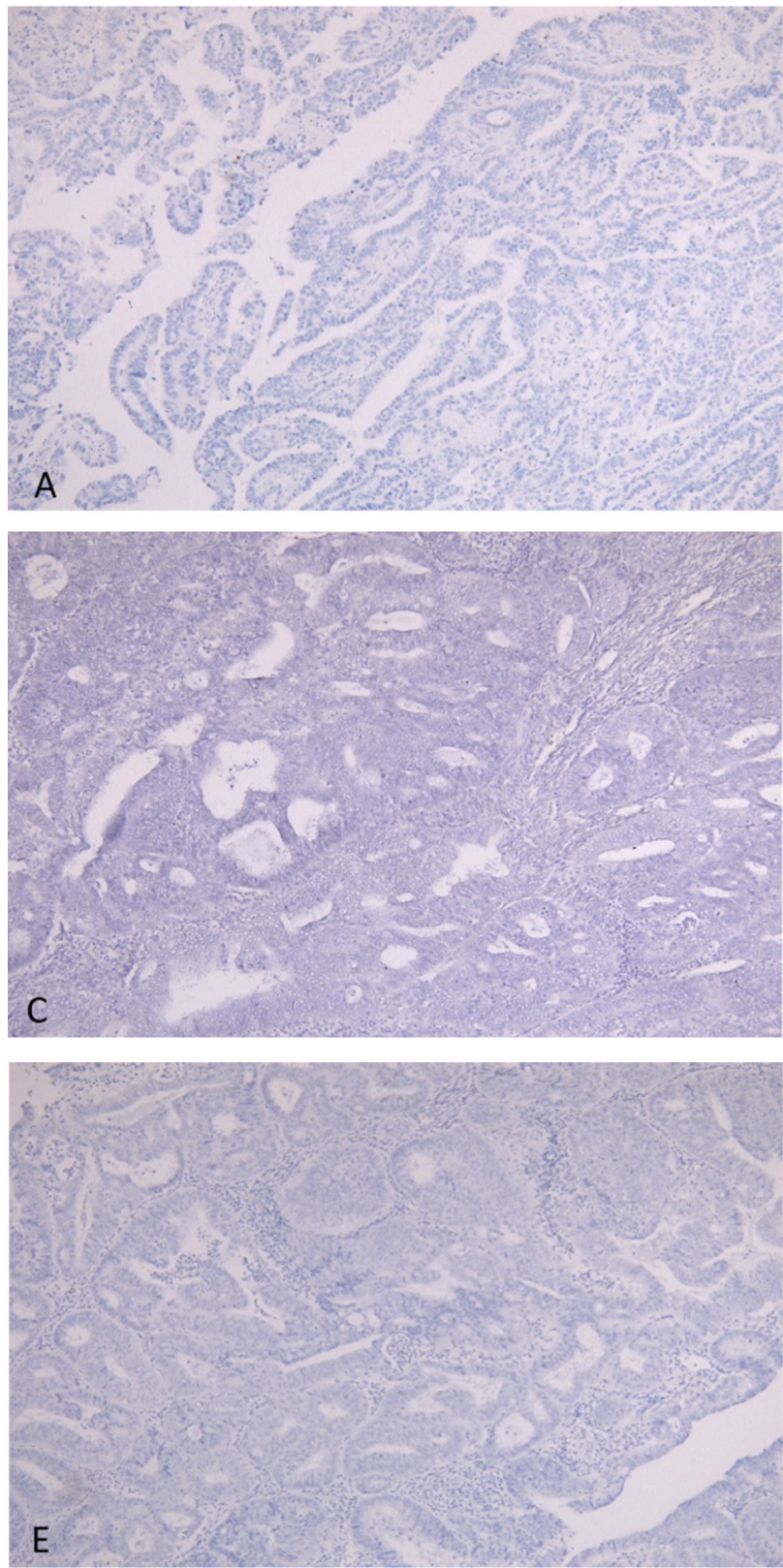

II) and favorable outcomes (5-year overall survival, 7590\%) [32-34]. However, patients who are diagnosed with advanced disease and patients with recurrent disease have poor prognosis when receiving conventional chemotherapy $[35,36]$. Therefore, we consider that the personalization of patient care is important.

In previous reports, the ratio of MSI in endometrial carcinoma is $15-30 \%$ [37-39]. In the present study, 42/149 (28.2\%) patients were MSI-positive. There are different techniques for the identification of MMR deficiency [4045]. Primarily, MSI analysis and IHC of MMR proteins are used to determine whether tumors are MSI-positive. MSI analysis has primarily been utilized in research, not
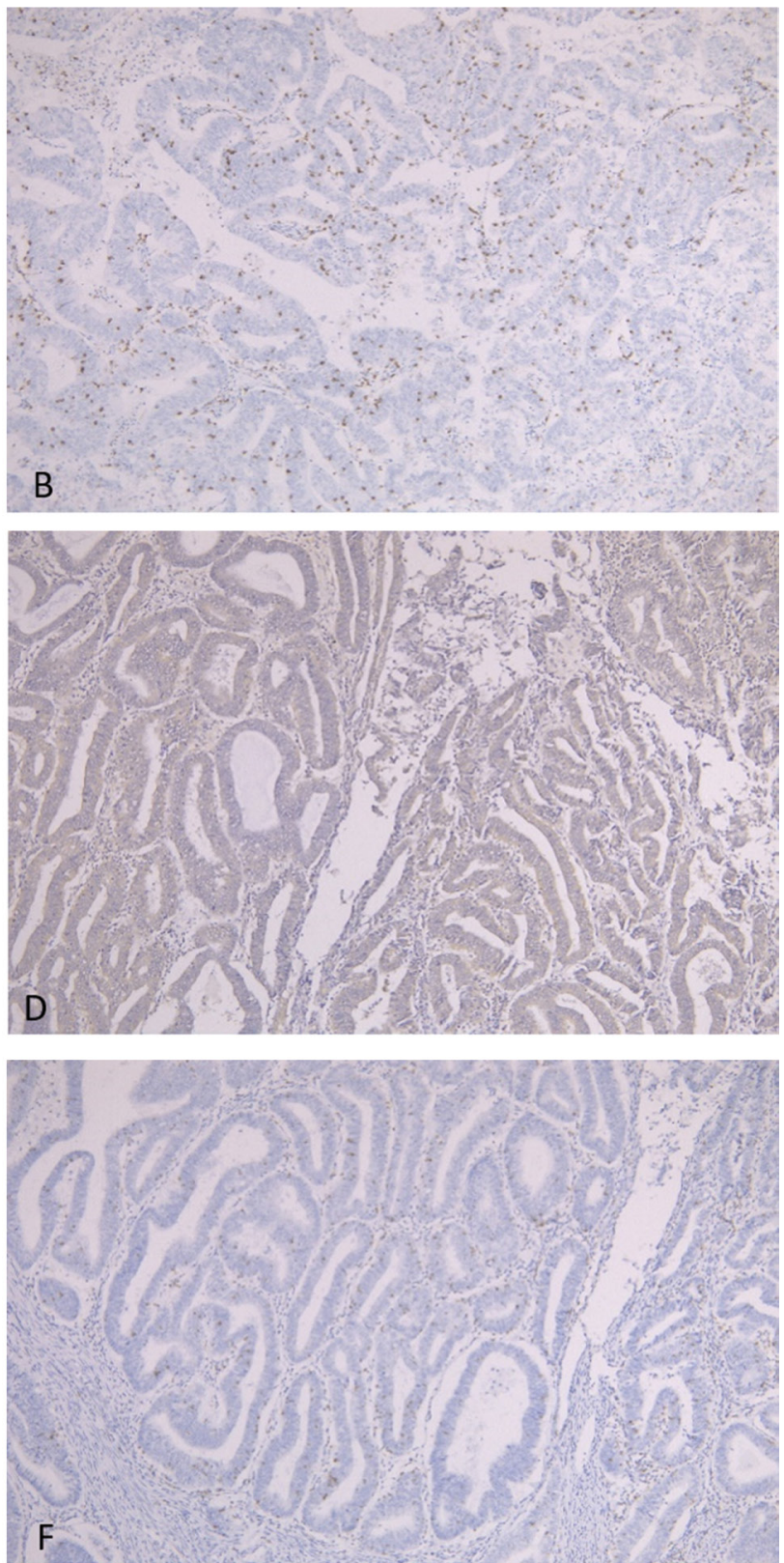

Figure 2: A., B., Immunostaining of CD8. A, CD8 expression score of 0. B, CD8 expression score of 3+. C., D. Immunostaining of PDL1. C, no expression of PD-L1. D, positive expression of PD-L1. E., F. Immunostaining of PD-1: E, no expression of PD-1. F, positive expression of PD-1. 
clinical practice, and requires DNA extraction from the tumor as well as normal tissue or blood for comparison. High concordance between IHC of MMR proteins and MSI has been reported [41]. Immunostaining of MMR proteins is simple and can be performed at any hospital. Moreover, it is more cost effective than MSI analysis. Therefore, we believe that IHC of MMR proteins should be used clinically to identify MSI-positive tumors. In MSI tumors, most cases are MLH1 or MSH2 deficient, but cases of PMS2 and MSH6 deficiency are also seen. Therefore, immunostaining of PMS2 and MSH6 is useful for MSI screening [46].

In the present study, more MSI cases than MSS cases showed CD8 positivity. Although lymphocyte infiltration is a good prognostic factor, there was no significant difference in OS between MSI cases and MSS cases in the current study. However, we also performed univariate analysis of PFS and OS separately in stage I/II and stage III/IV cases, and found that, in stage I/II cases, the MSI group had significantly shortened PFS compared to the MSS group. There was no significant difference between MSI and MSS in OS when stratifying by stage (Supplementary Figure 1,2). There have been reports indicating that MSI is a good prognostic factor in colorectal cancer and that MMR status does not contribute to prognosis in colorectal cancer [47, 48, 49]. There are many reports that there is no significant difference in survival rate between the MSI and MSS groups in endometrial cancer $[50,51,52,53]$. Taken together with the current results, the effect of MSI status on prognosis remains controversial. In the current study, as with CD8 expression, more MSI cases than MSS cases were positive for PD-1 and PD-L1. We hypothesize that, in MSI tumors, CD8 lymphocytes initially attack tumor cells, but the immune escape mechanism eventually works by raising
PD-L1 expression in tumor cells and PD-1 expression in lymphocytes. Therefore, tumor cells escape attack from immune cells and the tumor can progress (Figure 5). The immune escape mechanism functions in MSI tumors. Therefore, immune checkpoint inhibitors (antiPD-1, anti-PD-L1 antibodies) may be more effective in MSI cases than in MSS cases. The relationship between MSI and prognosis is thought to vary depending on the extent to which the immune escape mechanism is active. In this study, the group with high PD-L1 expression had significantly prolonged PFS. The relationship between PDL1 expression and prognosis has been studied in multiple cancer types. There are reports that PD-L1 expression is a good prognostic factor and, conversely, reports that PDL1 expression is a poor prognostic factor [ $54,55,56,57]$. Our hypothesis is that if PD-L1 expression is increased in cancer cells, the immune escape mechanism is activated in the tumor microenvironment, leading to poor prognosis. Since immune cells infiltrate the tumors before PD-L1 expression increases in MSI tumors, we speculate that patients with PD-L1 expression have a good short-term prognosis due to the influence of CD8 lymphocytes, which are a good prognostic factor. Evaluation of MSI in endometrial cancer is useful for determining whether a patient will respond to immune checkpoint therapy. While we were preparing this manuscript, there was a report that MSI-H endometrial tumors have increased immune cell infiltration and PD-L1 expression compared with MSS endometrial tumors [58]. We consider that their result supports our results.

Mutation burden is expected to be a biomarker for immune checkpoint inhibitors. It has been suggested that not only the number of neoantigens, but also the clonality of genetic abnormalities, may be important for predicting the therapeutic effect of immune checkpoint
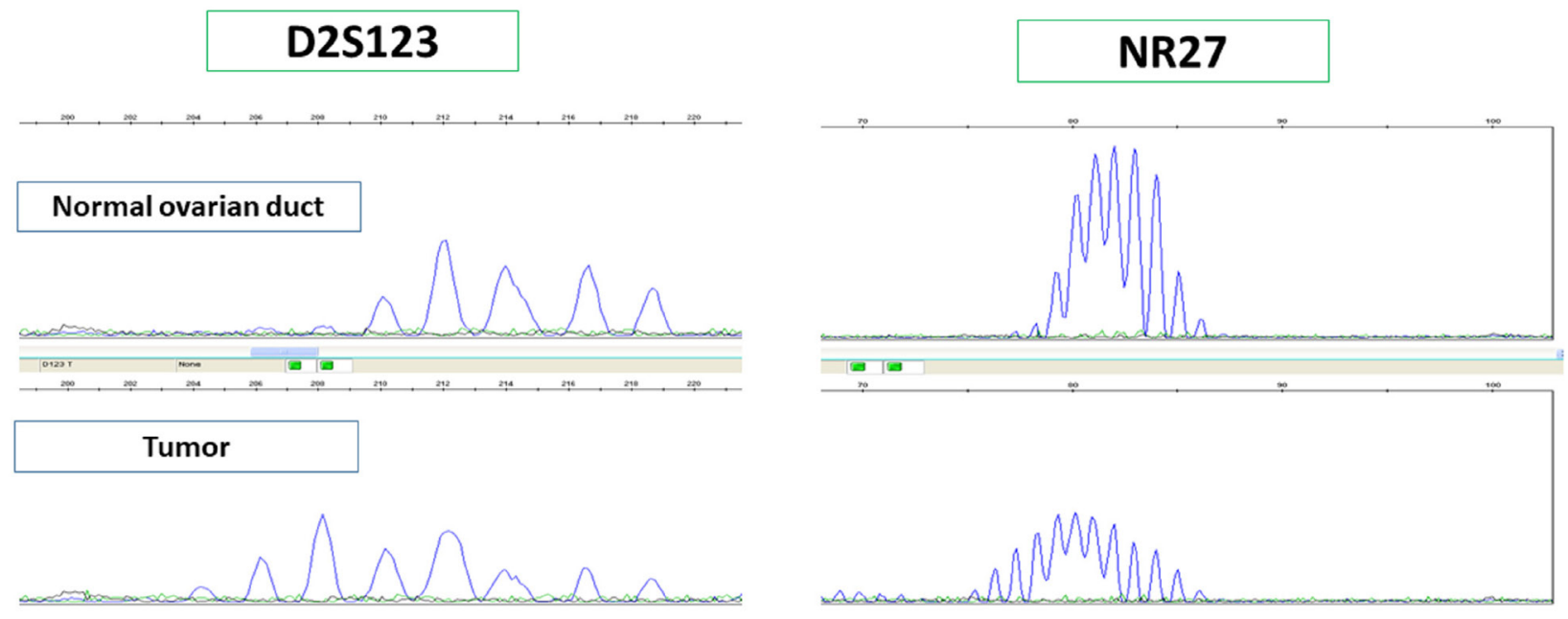

Figure 3: MSI analysis was performed in cases that were negative for one or more MMR protein by immunostaining to confirm MSI. 

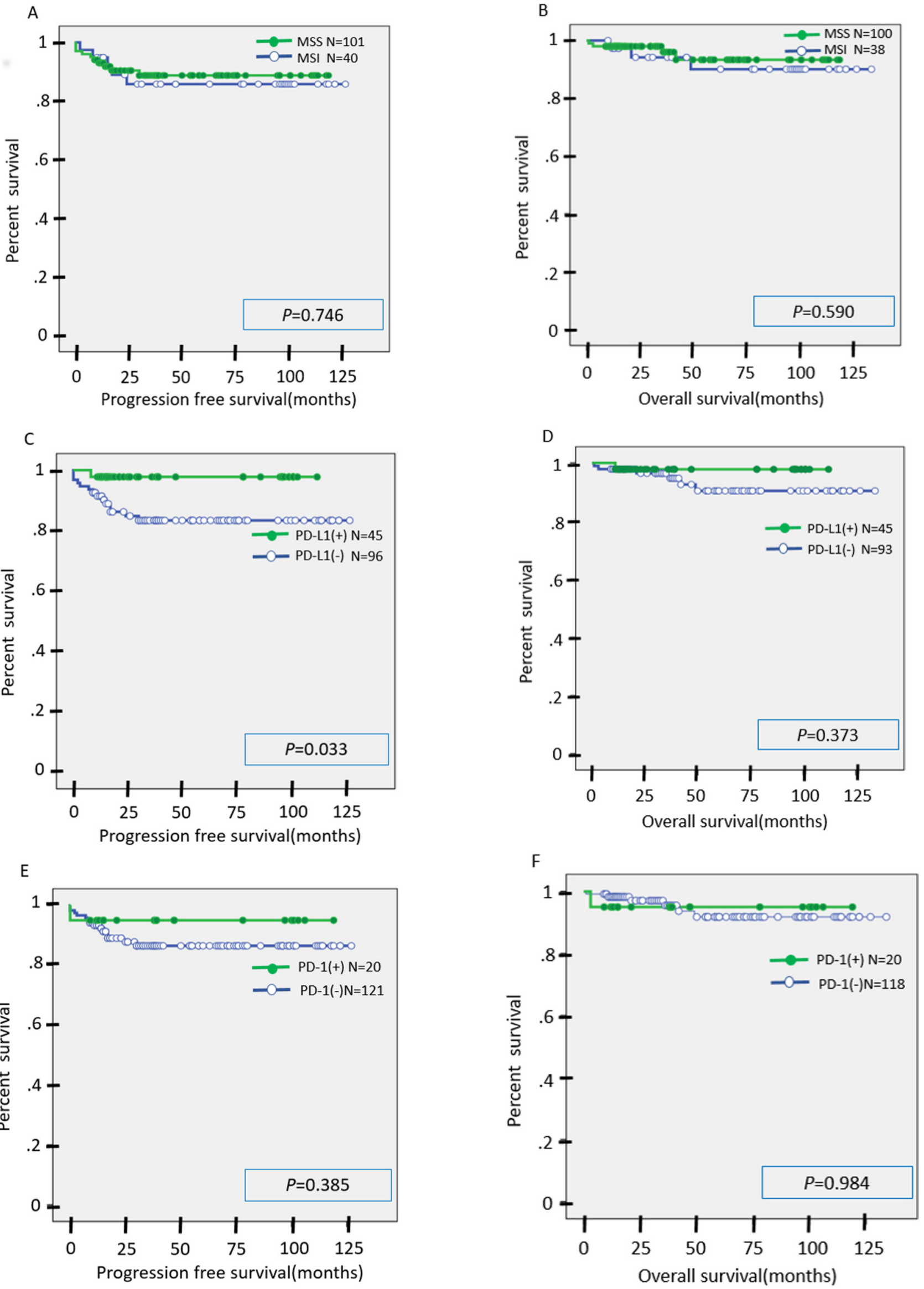
G

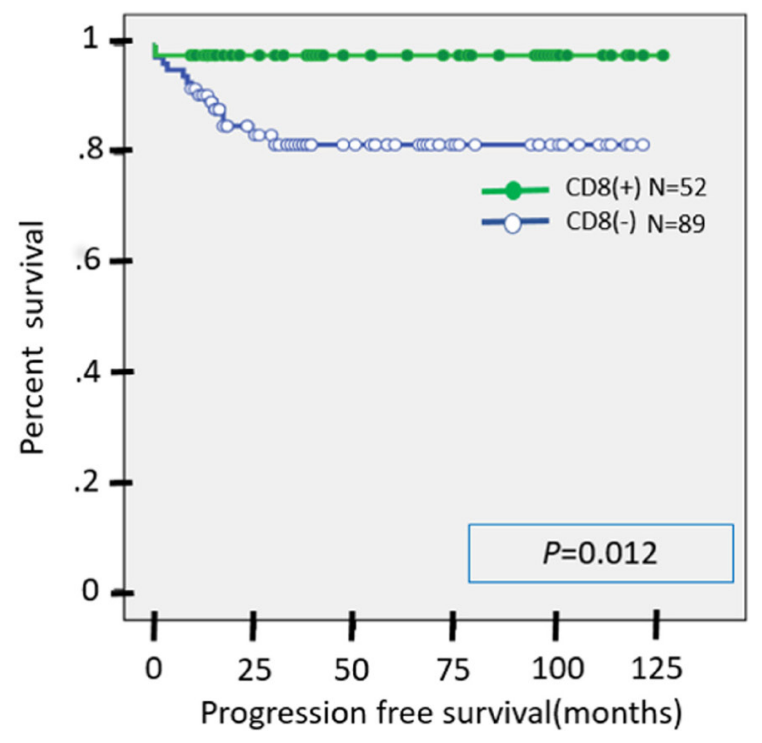

$\mathrm{H}$

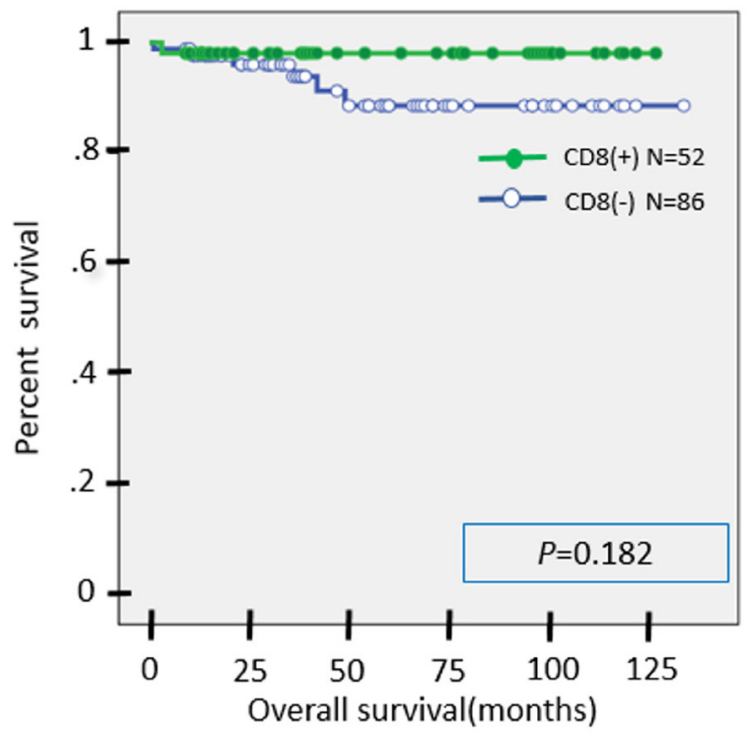

Figure 4: A., B. Kaplan-Meier analysis of progression-free (A) and overall (B) survival between the MSI group and MSS group. C., D. Kaplan-Meier analysis of progression-free (C) and overall (D) survival between the PD-L1(+) group and PD-L1(-) group. E., F. KaplanMeier analysis of progression-free (E) and overall (F) survival between the PD-1(+) group and PD-1(-) group. G., H. Kaplan-Meier analysis of progression-free $(\mathrm{G})$ and overall $(\mathrm{H})$ survival between the CD8(+) group and CD8(-) group.

inhibitors [59]. Moreover, previous studies have found that genetic abnormalities are heterogeneous, even within the same tumor, and it is obvious that neoantigens clonally expressed in the tumor are infiltrated by CD8 positive $\mathrm{T}$ cells that have high expression of PD-1 [59, 60]. It has been reported that immune checkpoint inhibitors have more efficacy in cases with many clonal genetic abnormalities and mutation burden rich cases [59, 60]. In endometrial cancers that are mutation burden rich because of POLE mutations, the immune checkpoint molecules are highly expressed, suggesting the possibility that immune checkpoint inhibitor treatment may be effective [61]. Currently, we are investigating whether immune checkpoint inhibitors are also effective for Japanese endometrial cancer patients with POLE mutations.

Not only positive predictive factors for immune checkpoint inhibitors, but also negative biomarkers, have been reported. Loss of PTEN and inactivation of the IFN- $\gamma / \mathrm{JAK} / \mathrm{STAT}$ pathway have been reported as negative biomarkers for response to immune checkpoint inhibitors [62-64]. Work is now ongoing to evaluate whether these factors are also negative biomarkers for immune checkpoint inhibitors in endometrial carcinoma. In addition to PD1/PD-L1, CTLA4 has recently received attention as an immune checkpoint molecule. CTLA4 is expressed in activated $\mathrm{T}$ cells and regulatory $\mathrm{T}$ cells and has an immunosuppressive function. Anti-CTLA4 antibody has been reported to prolong survival in progressive melanoma and was approved by the FDA as an immune checkpoint inhibitor against progressive melanoma in 2011 [65]. We are currently investigating whether anti-CTLA4 antibody is also effective in endometrial cancer.

In summary, various biomarkers of response to immune checkpoint inhibitors have been reported. In this study, PD-1 and PD-L1 expression were significantly higher by immunostaining in MSI cases of endometrial carcinoma as compared to MSS cases. In May 2017, the Food and Drug Administration approved the use of the PD-1 antibody pembrolizumab for solid cancers with MSI-H or MMR-deficiency [66]. Our data support the idea that immune checkpoint inhibitors could be effective in MSI cases of endometrial cancer, even in Japanese populations; however, this should be directly tested, preferably in a large cohort, prospective study. The presence or absence of MSI by immunostaining may be a biomarker for immune checkpoint inhibitors.

\section{MATERIALS AND METHODS}

\section{Ethics statement}

This investigation was conducted in accordance with the ethical standards and according to the Declaration of Helsinki and national and international guidelines, and has been approved by the institutional review board of Shimane University Hospital. Tumor specimens were collected after obtaining written consent from all patients with the approval of the Facility Ethical Committee (Shimane University Hospital; approval no. 2004-0381). 


\section{Tissue samples}

Samples were collected from 149 patients with endometrioid-type endometrial carcinomas treated between January 2006 and January 2017 in the Department of Obstetrics and Gynecology at the Shimane University Hospital. The samples were formalin-fixed and paraffinembedded tissue blocks. The tumors were diagnosed based on conventional morphological examination of hematoxylin and eosin-stained sections.

Endometrial carcinomas were classified according to the surgical staging system of the International Federation of Gynecology and Obstetrics (FIGO 2008) [29]. All tumors were classified histologically according to the World Health Organization criteria.

The relevant clinical data were collected by retrospective review of the patients' files. The follow-up period ranged from 1 month to 134 months, with a median follow-up of 38 months.

\section{Immunohistochemistry}

Expression of mismatch repair (MMR) proteins (MLH1, PMS2, MSH2, and MSH6), CD8, PD-L1, and PD-1 was evaluated by immunohistochemistry (IHC).

Formalin-fixed and paraffin-embedded sections (4$\mu \mathrm{m}$ thick) were dewaxed in xylenes and hydrated in graded alcohol. After antigen retrieval in a sodium citrate buffer, slides were incubated overnight at $4{ }^{\circ} \mathrm{C}$ with antibodies against MutS Protein Homolog 2 (1:50; Dako, Santa Clara, CA, United States), MutS Protein Homolog 6 (1:50; Dako), Postmeiotic Segregation Increased 2 (1:40; Dako), MutL Protein Homolog 1 (1:50; Dako), CD-8 (1:100; Roche, Basel, Switzerland), PD-L1 (ab205921, Abcam, Cambridge, United Kingdom), and PD-1 (Roche). Two researchers who were blinded to the clinicopathological factors evaluated the samples by a light microscope.

\section{Definition of MSI and CD8/PD-1/ PD-L1 positivity by IHC}

Tumors were considered MSI if at least one of the four MMR proteins (MSH2, MSH6, PMS2, or MLH1) was negative.

The population density of tumor infiltrating lymphocytes was stratified into four categories by CD8 staining: 0 , undetectable; $1+$, low density $(0-30 \%) ; 2+$, moderate density (30-60\%); and $3+$, high density $(\geq 60 \%)$. Cases that were $2+$ or $3+$ were counted as positive in our analysis. For PD-L1, tumors with staining in $\geq 5 \%$ of the tumor cells (membranous and cytoplasmic staining) were considered positive. For PD-1, cases with staining in $\geq$ $5 \%$ of the tumor infiltrating lymphocytes were considered positive.
A

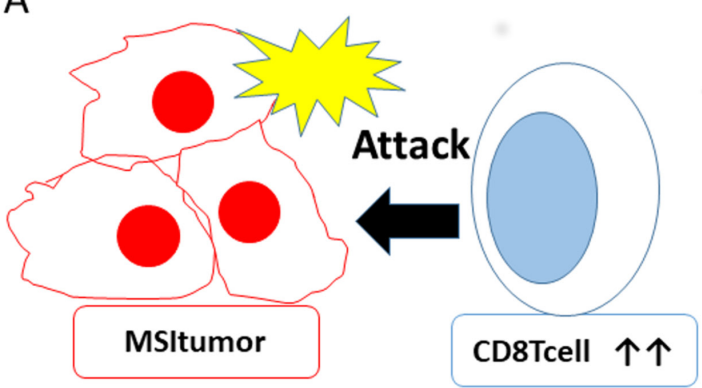

B

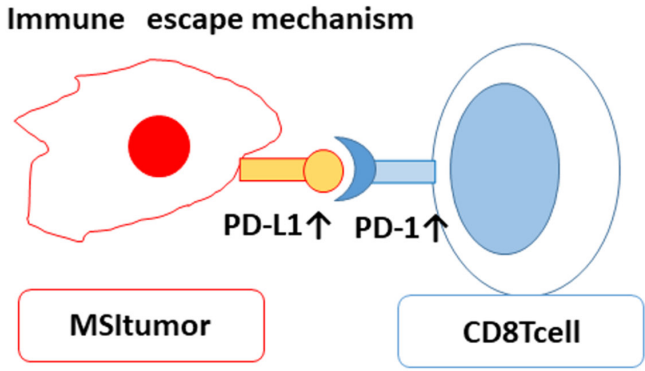

C

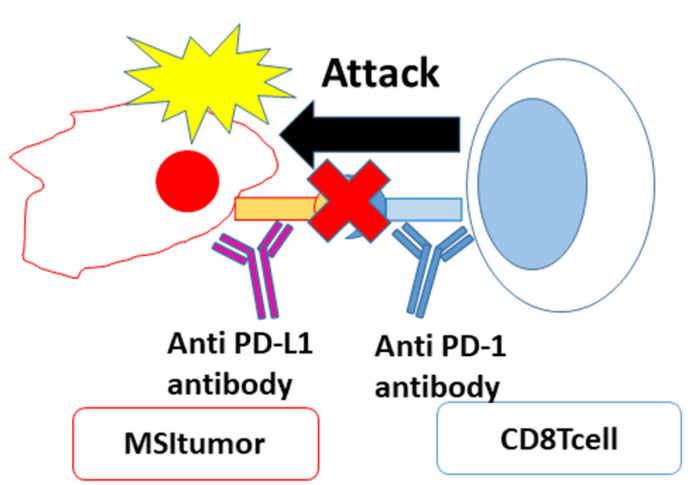

Figure 5: MSI allows tumor cells to escape the immune response and can be targeted by immune checkpoint inhibitors. A. CD8 lymphocytes initially attack tumors cells. B. When PD-L1 on tumor cells binds PD-1 on immune cells, the immune escape mechanism is activated. C. Treatment with PD-1 and PD-L1 inhibitors can block this immune escape mechanism. 


\section{DNA extraction and microsatellite instability analysis}

To validate the evaluation of MSI by immunostaining, we conducted microsatellite instability analysis in 12 cases evaluated as MSI by immunostaining. We digested tumor tissues $(0.01 \mathrm{M} \mathrm{NaCl} ; 0.5 \mathrm{M}$ Tris$\mathrm{HCl}, \mathrm{pH}$ 8.0; $20 \mathrm{mM}$ EDTA; 0.05\% Tween-20; $0.1 \mathrm{mg} /$ $\mathrm{mL}$ proteinase $\mathrm{K}$ ) overnight at $58^{\circ} \mathrm{C}$. To inactivate the proteinase $\mathrm{K}$, we heated the tissues to $95^{\circ} \mathrm{C}$ for $10 \mathrm{~min}$. After that, DNA was extracted with phenol/chloroform treatment and ethanol precipitation. We performed MSI analysis using the polymerase chain reaction (PCR) with eight microsatellite markers (BAT25, BAT26, D2S123, D5S346, D17S250, NR21, MONO27, and NR2). PCR was performed in a total volume of $10 \mu \mathrm{L}$ containing $25-50 \mathrm{ng}$ of DNA, each sense primer, $20 \mu \mathrm{M}$ dNTPs, $0.4 \mu \mathrm{M}$ of each primer, and 0.25 units of TKs Gflex DNA polymerase (Takara Shuzo, Shiga, Japan). We heated the mixtures at $94^{\circ} \mathrm{C}$ for $10 \mathrm{~min}$, and PCR was performed for 45 cycles at $94^{\circ} \mathrm{C}$ for $30 \mathrm{~s}$, at the appropriate annealing temperature for $30 \mathrm{~s}$, and at $72^{\circ} \mathrm{C}$ for $1 \mathrm{~min}$ each, followed by $72^{\circ} \mathrm{C}$ for $10 \mathrm{~min}[30]$.

We analyzed the amplicons on the ABI PRISM 310 Genetic Analyzer and evaluated allelic sizes by GeneMapper (Applied Biosystems, Thermo Fisher K. K, Yokohama, Japan). These markers include the recommended markers for the detection of MSI proposed at the National Cancer Institute collaborative meeting on MSI in colorectal carcinoma [31]. When two or more markers showed length variation between the fallopian tube samples (used as normal tissue controls) and the tumor samples, we judged the cases to be MSI. When none of the markers showed length variations between the fallopian tube samples and the tumor samples, we judged the cases to be MSS.

\section{Statistical analyses}

Chi-squared tests were used to analyze the association between MSI and the expression of CD8, PD-1, and PD-L1. Univariate analysis was performed using binomial logistic regression for ordered categorical variables. The endpoints of the analysis were progressionfree survival (PFS) and overall survival (OS). PFS and OS were calculated between the date of diagnosis and the date of first relapse and last follow-up, respectively. Because 11 patients were lost to follow-up due to transfer, for univariate analysis we analyzed PFS in 141 patients and OS in 138 patients. Data were plotted as Kaplan-Meier curves, and statistical significance was determined using the log-rank test. In the present study, p-values below 0.05 were considered statistically significant.

\section{Abbreviations}

FIGO: International Federation of Gynecology and Obstetrics, IHC: immunohistochemistry, MSI: microsatellite instability, MMR: mismatch repair, OS: overall survival, PCR: polymerase chain reaction, PD-1: programmed cell death-1, PD-L1: programmed cell deathligand 1, PFS: progression-free survival

\section{Author contributions}

Hitomi Yamashita and Kentaro Nakayama drafted the manuscript. Kohei Nakamura, Tomoka Ishibashi, Masako Ishikawa, Kaori Sanuki, Ruriko Ono, and Razia Sultana carried out the immunohistochemical analysis and molecular genetic studies. Noriyoshi Ishikawa carried out pathological diagnosis. Kentaro Nakayama participated in the design of the study. Satoru Kyo conceived of the study, participated in its design and coordination, and helped draft the manuscript. All authors read and approved the final manuscript.

\section{CONFLICTS OF INTEREST}

The authors declare no potential conflicts of interest.

\section{FINANCIAL SUPPORT}

This study was supported by grants from the Ministry of Education, Culture, Sports, Science and Technology in Japan (15K10717).

\section{REFERENCES}

1. Dunn GP, Bruce AT, Ikeda H, Old LJ, Schreiber RD. Cancer immunoediting: from immunosurveillance to tumor escape. Nat Immunol. 2002; 3: 991-998.

2. Schreiber RD, Old LJ, Smyth MJ. Cancer immunoediting: integrating immunity's roles in cancer suppression and promotion. Science. 2011; 331:1565-1570.

3. Greenwald RJ, Freeman GJ, Sharpe AH. The B7 family revisited. Annu Rev Immunol. 2005; 23: 515-548.

4. Hamid O, Robert C, Daud A, Hodi FS, Hwu WJ, Kefford R, Wolchok JD, Hersey P, Joseph RW, Weber JS, Dronca R, Gangadhar TC, Patnaik A, et al. Safety and tumor responses with lambrolizumab (anti-PD-1) in melanoma. N Engl J Med. 2013; 369: 134-144.

5. Powles T, Eder JP, Fine GD, Braiteh FS, Loriot Y, Cruz C, Bellmunt J, Burris HA, Petrylak DP, Teng SL, Shen X, Boyd Z, Hegde PS, et al. MP-DL3280A (anti-PD-L1) treatment leads to clinical activity in metastatic bladder cancer. Nature. 2014; 515: 558-562.

6. Topalian SL, Hodi FS, Brahmer JR, Gettinger SN, Smith 
DC, McDermott DF, Powderly JD, Carvajal RD, Sosman JA, Atkins MB, Leming PD, Spigel DR, Antonia SJ, et al. Safety, activity, and immune correlates of anti-PD-1 antibody in cancer. N Engl J Med. 2012; 366: 2443-2454.

7. Ansell SM, Lesokhin AM, Borrello I, Halwani A, Scott EC, Gutierrez M, Schuster SJ, Millenson MM, Cattry D, Freeman GJ, Rodig SJ, Chapuy B, Ligon AH, et al. PD-1 blockade with nivolumab in relapsed or refractory Hodgkin's lymphoma. N Engl J Med. 2015; 372: 311-319.

8. Nghiem PT, Bhatia S, Lipson EJ, Kudchadkar RR, Miller NJ, Annamalai L, Berry S, Chartash EK, Daud A, Fling SP, Friedlander PA, Kluger HM, Kohrt HE, et al. PD-1 Blockade with Pembrolizumab in Advanced Merkel-Cell Carcinoma. N Engl J Med. 2016; 374: 2542-2552.

9. Herbst RS, Baas P, Kim DW, Felip E, Pérez-Garcia JL, Han JY, Molina J, Kim JH, Arvis CD, Ahn MJ, Majem M, Fidler MJ, de Castro G Jr, et al. Pembrolizumab versus docetaxel for previously treated, PD-L1-positive, advanced non-small-cell lung cancer (KEYNOTE-010): a randomised controlled trial. Lancet. 2016; 387: 1540-1550.

10. Borghaei H, Paz-Ares L, Horn L, Spigel DR, Steins M, Ready NE, Chow LQ, Vokes EE, Felip E, Holgado E, Barlesi F, Kohlhäufl M, Arrieta O, et al. Nivolumab versus Docetaxel in Advanced Nonsquamous Non-Small-Cell Lung Cancer. N Engl J Med. 2015; 373:1627-1639.

11. Taube JM, Klein A, Brahmer JR, Xu H, Pan X, Kim JH, Chen L, Pardoll DM, Topalian SL, Anders RA. Association of PD-1, PD-1 ligands, and other features of the tumor immune microenvironment with response to anti-PD-1 therapy. Clin Cancer Res. 2014; 20: 5064-5074.

12. Spira AI, Park K, Mazieres J, Vansteenkiste JF, Rittmeyer A, Ballinger M, Waterkamp D, Kowanetz M, Mokatrin A, Fehrenbacher L. Efficacy, safety and predictive biomarker results from a randomized phase II study comparing atezolizumab vs docetaxel in 2L/3L NSCLC (POPLAR). J Clin Oncol. 2015; 33: 8010.

13. Spigel DR, Chaft JE, Gettinger SN, Chao BH, Dirix LY, Schmid P, Chow LQM, Chappey C, Kowanetz M, Sandler A, Funke RP, Rizvi NA. Clinical activity and safety from a phase II study (FIR) of MPDL3280A (anti-PDL1) in PD-L1-selected patients with non-small cell lung cancer (NSCLC). J Clin Oncol. 2015; 33: 8028.

14. McLaughlin J, Han G, Schalper KA, Carvajal-Hausdorf D, Pelekanou V, Rehman J, Velcheti V, Herbst R, LoRusso P, Rimm DL. Quantitative Assessment of the Heterogeneity of PD-L1 Expression in Non-Small-Cell Lung Cancer. JAMA Oncol. 2016; 2: 46-54.

15. Ilie M, Long-Mira E, Bence C, Butori C, Lassalle S, Bouhlel L, Fazzalari L, Zahaf K, Lalvée S, Washetine K, Mouroux J, Vénissac N, Poudenx M, et al. Comparative study of the PD-L1 status between surgically resected specimens and matched biopsies of NSCLC patients reveal major discordances: a potential issue for anti-PD-L1 therapeutic strategies. Ann Oncol. 2016; 27:147-153.

16. Taube JM, Anders RA, Young GD, Xu H, Sharma R,
McMiller TL, Chen S, Klein AP, Pardoll DM, Topalian SL, Chen L. Colocalization of inflammatory Response with B7-H1 Expression in Human Melanocytic Lesions Supports an Adaptive Resistance Mechanism of Immune Escape. Sci Transl Med. 2012; 4: $127 \mathrm{ra37.}$

17. Alexandrov LB, Nik-Zainal S, Wedge DC, Aparicio SA, Behjati S, Biankin AV, Bignell GR, Bolli N, Borg A, Børresen-Dale AL, Boyault S, Burkhardt B, Butler AP, et al. Signatures of mutational processes in human cancer. Nature. 2013; 500: 415-421.

18. Le DT, Uram JN, Wang H, Bartlett BR, Kemberling $\mathrm{H}$, Eyring AD, Skora AD, Luber BS, Azad NS, Laheru D, Biedrzycki B, Donehower RC, Zaheer A, et al. PD-1 blockade in Tumors with Mismatch-Repair Deficiency. N Engl J Med. 2015; 372: 2509-2520.

19. Rizvi NA, Hellmann MD, Snyder A, Kvistborg P, Makarov V, Havel JJ, Lee W, Yuan J, Wong P, Ho TS, Miller ML, Rekhtman N, Moreira AL, et al. Mutational landscape determines sensitivity to PD-1 blockade in non-small cell lung cancer. Science. 2015; 348: 124-128.

20. Gibbons DL, Byers LA, Kurie JM. Smoking, p53 mutation, and lung cancer. Mol Cancer Res. 2014; 12: 3-13.

21. Gubin MM, Zhang X, Schuster H, Caron E, Ward JP, Noguchi T, Ivanova Y, Hundal J, Arthur CD, Krebber WJ, Mulder GE, Toebes M, Vesely MD, et al. Checkpoint blockade cancer immunotherapy targets tumour-specific mutant antigens. Nature. 2014; 515: 577-581.

22. Gargiulo P, Della Pepa C, Berardi S, Califano D, Scala S, Buonaguro L, Ciliberto G, Brauchli P, Pignata S. Tumor genotype and immune microenvironment in POLEultramutated and MSI-hypermutated Endometrial cancers: New candidates for checkpoint blockade immunotherapy? Cancer Treat Rev. 2016; 48: 61-68.

23. Pisani P, Bray F, Parkin DM. Estimates of the world-wide prevalence of cancer for 25 sites in the adult population. Int J Cancer. 2002; 97: 72-81.

24. Humber CE, Tierney JF, Symonds RP, Collingwood M, Kriwan J, Williams C, Green JA. Chemotherapy for advanced, recurrent or metastatic endometrial cancer: systematic review of Cochrane Collaboration. Ann Oncol. 2007; 18: 409-420.

25. Fleming GF. Systematic chemotherapy for uterine carcinoma: metastatic and adjuvant. J Clin Oncol. 2007; 25: 2983-2990.

26. Hoskins PJ, Swenerton KD, Pike JA, Wong F, Lim P, Acquino-Parsons C, Lee N. Paclitaxel and carboplatin, alone or with irradiation in advanced or recurrent endometrial cancer: a phase II study. J Clin Oncol. 2001; 19: 4048-4053.

27. van Wijk FH, Aapro MS, Bolis G, Chevallier B, van der Burg ME, Poveda A, de Oliveira CF, Tumolo S, Scotto di Palumbo V, Piccart M, Franchi M, Zanaboni F, Lacave $\mathrm{AJ}$, et al. Doxorubicin versus doxorubicin and cisplatin in endometrial carcinoma: definitive results of a randomized 
study by the EORTC Gynaecological Cancer Group. Ann Oncol. 2003; 14: 441-448.

28. Lincoln S, Blessing JA, Lee RB, Rocereto TF. Activity of paclitaxel as second-line chemotherapy in endometrial carcinoma: a Gynecologic Oncology Group study. Gynecol Oncol. 2003; 88: 277-281.

29. Pecorelli S. Revised FIGO staging for carcinoma of the vulva, cervix, and endometrium. Int J Gynaecol Obstet. 2009; 105:103-104.

30. Huan Z, Nakayama K, Nakayama N, Ishibashi M, Yeasmin S, Katagiri A, Purwana IN, Iida K, Maruyama R, Fukumoto M, Miyazaki K. Genetic classification of ovarian carcinoma based on microsatellite analysis: Relationship to clinicopathological features and patient survival. Oncol Rep. 2008; 19: 775-781.

31. Boland CR, Thibodeau SN, Hamilton SR, Sidransky D, Eshleman JR, Burt RW, Meltzer SJ, Rodriguez-Bigas MA, Fodde R, Ranzani GN, Srivastava S. A National Cancer Institute Workshop on Microsatellite Instability for cancer detection and familial predisposition; development of international criteria for the determination of microsatellite instability in colorectal cancer. Cancer Res. 1998; 58: 52485257.

32. Rose PG. Endometrial carcinoma. N Engl J Med. 1996; 335: 640-649.

33. Creasman WT, Odicino F, Maisonneuve P, Beller U, Benedet JL, Heintz AP, Ngan HY, Sideri M, Pecorelli S. Carcinoma of the corpus uteri. J Epidemiol Biostat. 2001; 6:47-86,

34. Morice P, Leary A, Creutzberg C, Abu-Rustum N, Darai E. Endometrial cancer. Lancet. 2016; 387: 1094-1108.

35. Ueda SM, Kapp DS, Cheung MK, Shin JY, Osann K, Husain A, Teng NN, Berek JS, Chan JK. Trends in demographic and clinical characteristics in women diagnosed with corpus cancer and their potential impact on the increasing number of deaths. Am J Obstet Gynecol. 2008; 198: 218.e1-6.

36. Del Carmen MG, Boruta DM 2nd, Schorge JO. Recurrent endometrial cancer. Clin Obstet Gynecol Oncol. 2012; 127: 651-661.

37. Stelloo E, Nout RA, Osse EM, Jürgenliemk-Schulz IJ, Jobsen JJ, Lutgens LC, van der Steen-Banasik EM, Nijman HW, Putter H, Bosse T, Creutzberg CL, Smit VT. Improved Risk Assessment by Integrating Molecular and Clinicopathological Factors in Early-stage Endometrial cancer combined Analysis of the PORTEc Cohorts. Clin Cancer Res. 2016; 22: 4215-4224.

38. Kanopiene D, Smailyte G, Vidugiriene J, Bacher J. Impact of microsatellite instability on survival of endometrial cancer patients. Medicina (Kaunas). 2014; 50: 216-221.

39. Talhouk A, McConechy MK, Leung S, Li-Chang HH, Kwon JS, Melnyk N, Yang W, Senz J, Boyd N, Karnezis AN, Huntsman DG, Gilks CB, McAlpine JN. A clinically applicable molecular-based classification for endometrial cancers. Br J Cancer. 2015; 113: 299-310.

40. Umar A, Boland CR, Terdiman JP, Syngal S, de la Chapelle A, Rüschoff J, Fishel R, Lindor NM, Burgart LJ, Hamelin R, Hamilton SR, Hiatt RA, Jass J, et al. Revised Bethesda guidelines for hereditary nonpolyposis colorectal cancer (Lynch syndrome) and microsatellite instability. J Natl Cancer Inst. 2004; 96: 261-268.

41. McConechy MK, Talhouk A, Li-Chang HH, Leung S, Huntsman DG, Gilks CB, McAlpine JN. Detection of DNA mismatch repair (MMR) deficiencies by immunohistochemistry can effectively diagnose the microsatellite instability (MSI) phenotype in endometrial carcinomas. Gynecol Oncol. 2015; 137: 306-310.

42. Goodfellow PJ, Billingsley CC, Lankes HA, Ali S, Cohn DE, Broaddus RJ, Ramirez N, Pritchard CC, Hampel H, Chassen AS, Simmons LV, Schmidt AP, Gao F, et al. Combined microsatellite instability, MLH1 methylation analysis, and immunohistochemistry for Lynch Syndrome screening in endometrial cancers from GOG210: An NRG oncology and gynecologic oncology group study. J Clin Oncol. 2015; 33: 4301-4308.

43. Hall G, Clarkson A, Shi A, Langford E, Leung H, Eckstein RP, Gill AJ. Immunohistochemistry for PMS2 and MSH6 alone can replace a four antibody panel for mismatch repair deficiency screening in colorectal adenocarcinoma. Pathology. 2010; 42: 409-413.

44. Burgart LJ. Testing for defective DNA mismatch repair in colorectal carcinoma: a practical guide. Arch Pathol Lab Med. 2005; 129: 1385-1389.

45. Yamamoto H, Imai K. Microsatellite instability: an update. Arch Toxicol. 2015; 89: 899-921.

46. Yuan L, Chi Y, Chen W, Chen X, Wei P, Sheng W, Zhou X, Shi D. Immunohistochemistry and microsatellite instability analysis in molecular subtyping of colorectal carcinoma based on mismatch repair competency. Int J Clin Exp Med. 2015; 8: 20988-21000.

47. Popat S, Hubner R, Houlston RS. Systematic review of microsatellite instability and colorectal cancer prognosis. J Clin Oncol. 2005; 23: 609-618.

48. Guastadiseqni C, Colafranceschi M, Ottini L, Doqliotti E. Microsatellite instability as a marker of prognosis and response to therapy: a meta-analysis of colorectal cancer survival data. Eur J Cancer. 2010; 46: 2788-2798.

49. Toh J, Chapuis PH, Bokey L, Chan C, Spring KJ, Dent OF. Competing risks analysis of microsatellite instability as a prognostic factor in colorectal cancer. Br J Surq. 2017; 104 : 1250-1259.

50. Kanopiene D, Smailyte D, Vidugiriene J, Bacher J. Impact of microsatellite instability on survival of endometrial cancer patients. Medicina (Kaunas). 2014; 50: 216-221.

51. Ruiz I, Martin-Arruti M, Lopez-Lopez E, Garcia-Orad A. Lack of association between deficient mismatch repair expression and outcome in endometrial carcinomas of the endometrioid type. Gynecol Oncol. 2014; 134: 20-23. 
52. Diaz-Padilla I, Romero N, Amir E, Matias-Guiu X, Vilar E, Muggia F, Garcia-Donas J. Mismatch repair status and clinical outcome in endometrial cancer: A systematic review and meta-analysis. Crit Rev Oncol Hematol. 2013; 88: 154-167.

53. Steinbakk A, Maipica A, Slewa A, Gudlaugsson E, Janssen EA, Arends M, Kruse AJ, Yinhua Y, Feng W, Baak JP. High frequency microsatellite instability has a prognostic value in endometrial endometrioid adenocarcinoma, but only in FIGO stage 1 cases. Cell Oncol (Dordr). 2011; 34: 457-465.

54. Hanna GJ, Woo SB, Li YY, Barletta JA, Hammerman PS, Lorch JH. Tumor PD-L1 expression is associated with improved survival and lower recurrence risk in young women with oral cavity squamous cell carcinoma. Int J Oral Maxillofac Surg. 2017 Sep 29. [Epub ahead of print].

55. Wu Y, Cao D, Qu L, Cao X, Jia Z, Zhao T, Wang Q, Jiang J. PD-1 and PD-L1 co-expression predicts favorable prognosis in gastric cancer. Oncotarget. 2017; 8: 6406664082. https://doi.org/10.18632/oncotarget.19318.

56. Zhou C, Tang J, Sun H, Zheng X, Li Z, Sun T, Li J, Wang S, Zhou X, Sun H, Cheng Z, Zhang H, Ma H. PD-L1 expression as poor prognostic factor in patients with nonsquamous non-small cell lung cancer. Oncotarget. 2017; 8: 58457-58468. https://doi.org/10.18632/oncotarget.17022.

57. Hamanishi J, Mandai M, Iwasaki M, Okazaki T, Tanaka Y, Yamaguchi K, Higuchi T, Yagi H, Takakura K, Minato N, Honjo T, Fujii S. Programmed cell death 1 ligand 1 and tumor-infiltrating $\mathrm{CD} 8+\mathrm{T}$ lymphocytes are prognostic factors of human ovarian cancer. Proc Natl Acad Sci USA. 2007; 104: 3360-3365.

58. Pakish JB, Zhang Q, Chen Z, Liang H, Chisholm GB, Yuan Y, Mok SC, Broaddus RR, Lu KH, Yates MS. Immune Microenvironment in Microsatellite instable Endometrial Cancers; Hereditary or Sporadic Origin Matters. Clin Cancer Res. 2017; 23: 4473-4481.

59. McGranahan N, Furness AJ, Rosenthal R, Ramskov S, Lyngaa R, Saini SK, Jamal-Hanjani M, Wilson GA, Birkbak NJ, Hiley CT, Watkins TB, Shafi S, Murugaesu N, et al. Clonal neoantigens elicit $\mathrm{T}$ cell immunoreactivity and sensitivity to immune checkpoint blockade. Science. 2016; 351:1463-1469.
60. Greaves M. Evolutionary determinants of cancer. Cancer Discov. 2015; 5: 806-820.

61. Mehnert JM, Panda A, Zhong H, Hirshfield K, Damare S, Lane K, Sokol L, Stein MN, Rodriguez-Rodriquez L, Kaufman HL, Ali S, Ross JS, Pavlick DC, et al. Immune activation and response to pembrolizumab in POLE-mutant endometrial cancer. J Clin Invest. 2016;126: 2334-2340.

62. Peng W, Chen JQ, Liu C, Malu S, Creasy C, Tetzlaff MT, Xu C, McKenzie JA, Zhang C, Liang X, Williams LJ, Deng $\mathrm{W}$, Chen $\mathrm{G}$, et al. Loss of PTEN promotes resistance to T cell-mediated immunotherapy. Cancer Discov. 2016; 6: 202-216.

63. Zaretsky JM, Garcia-Diaz A, Shin DS, Escuin-Ordinas H, Hugo W, Hu-Lieskovan S, Torrejon DY, Abril-Rodriguez G, Sandoval S, Barthly L, Saco J, Homet Moreno B, Mezzadra R, et al. Mutations Associated with Acquired Resistance to PD-1 Blockade in Melanoma. N Engl J Med. 2016; 375: 819-829.

64. Shin DS, Zaretsky JM, Escuin-Ordinas H, Garcia-Diaz A, Hu-Lieskovan S, Kalbasi A, Grasso CS, Hugo W, Sandoval S, Torrejon DY, Palaskas N, Rodriguez GA, Parisi G, et al. Primary Resistance to PD-1 Blockade Mediated by JAK1/2 mutations. Cancer Discov. 2017; 7: 188-201.

65. Hodi FS, O'Day SJ, McDermott DF, Weber RW, Sosman JA, Haanen JB, Gonzalez R, Robert C, Schadendorf D, Hassel JC, Akerley W, van den Eertwegh AJ, Lutzky J, et al. Improved survival with ipilimumab in patients with metastatic melanoma. N Engl J Med. 2010; 363: 711-723.

66. U.S. Food \& Drug Administration. FDA approves first cancer treatment for any solid tumor with a specific genetic feature.

https://www.fda.gov/newsevents/newsroom/ pressannouncements/ucm560167.htm 